\title{
Integrated geochemical study of Chichali Formation from Kohat sub-basin, Khyber Pakhtunkhwa, Pakistan
}

\author{
Shah Faisal Zeb ${ }^{1}$ - Muhammad Zafar ${ }^{1} \cdot$ Samina Jehandad ${ }^{2} \cdot$ Tahseenullah Khan $^{1} \cdot$ Syed Mamoon Siyar ${ }^{3}$. \\ Anwar Qadir $^{4}$
}

Received: 8 December 2019 / Accepted: 20 June 2020 / Published online: 8 July 2020

(c) The Author(s) 2020

\begin{abstract}
An integrated geochemical study was performed for the assessment of the hydrocarbon potential, environment of deposition, thermal maturity and the organic matter's source of the Chichali Formation in the Kohat sub-basin of Pakistan. The analytical techniques used included the total organic carbon (TOC), Rock-Eval (RE), organic petrography, column chromatography (CC) and gas chromatography mass spectrometry (GC-MS). The quantity of the organic matter (i.e., TOC), Rock-Eval parameters (such as the original hydrogen index, oxygen index and $T_{\max }$ ) and maceral analyses revealed that the shales of the Chichali Formation have poor to good petroleum source potential with Kerogen type II presently shown as type III (hydrogen index, oxygen index and $T_{\max }$ ) due to thermal maturation and with higher marine organic matter. The extracts of the rock samples have high amount of short-chain n-alkanes with high ratios of tricyclic terpanes to hopanes (TCT/H), $\mathrm{C}_{27}$ to $\mathrm{C}_{29}$ stranes and low ratios of pristane to phytane $(\mathrm{Pr} / \mathrm{Ph}), \mathrm{C}_{19} / \mathrm{C}_{23}$ TCT and $\mathrm{C}_{20} / \mathrm{C}_{23}$ TCT. These ratios and lack of terrestrial biomarker (oleanane) are pointing toward algal/marine organic source deposited under anoxic environment. The dibenzothiophene-to-phenanthrene ratios (DBT/P) versus $\mathrm{Pr} / \mathrm{Ph}$ cross-plot also confirms the anoxic environment with sulfate poor mixed shale/carbonate lithology. The drill cuttings show relatively high maturity compared to outcrop samples indicated by n-alkanes ratios, isoprenoids vs n-alkanes cross-plot, methyl-phenanthrene index (MPI-1), methyl-dibenzothiophene ratios and absence of saturate biomarkers. All the above findings reveal that the Chichali Formation had mature algal source with anoxic environment of deposition and may prove to be a poor to good hydrocarbon source rock.
\end{abstract}

Keywords Chichali Formation $\cdot$ Geochemical study $\cdot$ Kohat sub-basin $\cdot$ Pakistan

\section{Introduction}

The EW-trending Kohat sub-basin is one of the major hydrocarbon-producing areas in northern Pakistan having various proven and potential plays. The sedimentary succession

Shah Faisal Zeb

shahfaisalzeb@gmail.com

Muhammad Zafar

dr.zafar@bui.edu.pk

Samina Jehandad

samojahandad@gmail.com

Tahseenullah Khan

dr.tahseen@bui.edu.pk

Syed Mamoon Siyar mamoon280@yahoo.com

Anwar Qadir anwarq@uoh.edu.pk of the Kohat sub-basin was deposited on the northwestern margin of the Indian plate, ranging in age from Jurassic to Quaternary (Wandrey et al. 2004). According to Meissner et al (1974), the total stratigraphic thickness of this basin is greater than $7700 \mathrm{~m}$. The major hydrocarbon discoveries

1 Department of Earth and Environmental Sciences, Bahria University, Islamabad 44000, Pakistan

2 Hydrocarbon Development Institute of Pakistan (HDIP), Islamabad 44000, Pakistan

3 Department of Geology, University of Malakand, Lower Dir, Khyber Pakhtunkhwa 18800, Pakistan

4 Department of Geology, University of Haripur, Khyber Pakhtunkhwa 22620, Pakistan 
in the basin include Chanda, Nashpa, Mela, Makori and Manzalai oil-gas-condensate fields. The Samana Suk and Datta formations of Jurassic, Lumshiwal and Kawagarh formations of Cretaceous, and Lockhart and Patala formations of Paleocene age are the main reservoirs in the study area. The limestone of Lockhart Formation and shales of Datta, Chichali, Hangu and Patala formations appear to be the source rocks for hydrocarbons (Table 1).

The organic matter's characterization in the sedimentary rocks is one of the important criteria for the determination of a petroleum prospect in a basin. TOC is a valuable parameter for the evaluation of petroleum source rocks. Rocks with TOC less than $0.5 \mathrm{wt} \%$ have poor, with TOC 0.5 to $1 \mathrm{wt} \%$ have fair, with TOC $1-2 \mathrm{wt} \%$ have good, with TOC $2-4 \mathrm{wt} \%$ have very good and with TOC greater than $4 \mathrm{wt} \%$ are considered to have excellent potential for hydrocarbons (Peters and Cassa 1994). The Rock-Eval pyrolysis data have been extensively used to evaluate the organic matter type, maturity and its potential for hydrocarbons in different basins (Espitalié et al. 1985; Peters 1986; Peters and Cassa 1994; Langford and Blanc-Valleron 1990). The thermal maturity level is a function of vitrinite reflectance, $T_{\max }$ (pyrolysis temperature representing maximum yield of hydrocarbons) and production index (PI), depending upon the nature of the organic matter (Bacon et al. 2000; Peters and Cassa 1994). The specific complex compounds present in the source rocks' extracts derived from the living organisms are called biomarkers which are the survivors of the processes of diagenesis and catagenesis (Peters et al. 2005). Biomarkers can be used for the assessment of depositional environment, maturity, kerogen type and the source of organic matter in sediments (Peters et al. 1993). The commonly applied biomarkers are the n-alkanes, acyclic isoprenoids, terpanes, steranes, dibenzothiophene and phenantrene. The organic compounds produced from the marine algae and photosynthetic bacteria have comparatively more concentration of short-chain n-alkanes (i.e., $\mathrm{nC}_{15}, \mathrm{nC}_{17}$ and $\mathrm{nC}_{19}$ ), whereas the organic matter related to vascular plants is dominated by long-chain $\mathrm{n}$-alkanes $\left(\mathrm{nC}_{27}, \mathrm{nC}_{29}\right.$ and $\mathrm{nC}_{31}$ ) (Tenzer et al. 1999; Cranwell et al. 1987). The acyclic isoprenoid compounds such as pristane $(\mathrm{Pr})$ and phytane $(\mathrm{Ph})$ have been applied to know about the environment of deposition of the petroleum's source rocks (Didyk et al. 1978; Powell and McKirdy 1973). The source rock extracts or crude oils derived from marine and saline lacustrine source have abundant $\mathrm{C}_{23}$ tricyclic terpanes $\left(\mathrm{C}_{23} \mathrm{TCT}\right)$, whereas the terrestrial oils or source rock extracts are dominated by $\mathrm{C}_{19}$ tricyclic terpanes $\left(\mathrm{C}_{19}\right.$ TCT) and $\mathrm{C}_{20}$ tricyclic terpanes $\left(\mathrm{C}_{20}\right.$ TCT) (Peters et al. 1993). The saturate biomarker ratio such as $C_{31}$ $22 \mathrm{~S} /(22 \mathrm{~S}+22 \mathrm{R})$ homohopane ratio attains equilibrium in range of 0.57 to 0.62 and indicates early oil generation phase (Seifert and Moldowan 1980). Similarly, with an increase in thermal maturity, the $\mathrm{C}_{29}$ sterane isomerization ratio, i.e., $\mathrm{C}_{29} 20 \mathrm{~S} /(20 \mathrm{~S}+20 \mathrm{R})$, rises from 0 to $\sim 0.5$, attains equilibrium in the range of $0.52-0.55$ and indicates oil generation (Seifert and Moldowan 1986). The $\mathrm{C}_{29} \beta \beta / \alpha \alpha+\beta \beta$ sterane ratio rises from 0 to $\sim 0.7$ as thermal maturity increases and attains equilibrium in the range of 0.67-0.71 (Peters et al. 2005). Similarly, the most commonly applied aromatic maturity parameters are based on molecular ratios of substituted naphthalenes $(\mathrm{N})$, phenanthrenes $(\mathrm{P})$ and dibenzothiophenes (DBT). The methyl-phenanthrene (MP) isomers abundance changes with variation in source thermal maturity and has therefore been correlated with vitrinite reflectance $\left(\mathrm{R}_{\mathrm{o}}\right)$ (Radke et al. 1982). A similar trend has been observed by others (Radke 1988; Chakhmakhchev and Suzuki 1995) for methyl-dibenzothiophene (MDBT) with increasing maturity.

The studies related to stratigraphy, sedimentology and structural architecture of the sedimentary succession have been reported with little source rocks' interpretation (based only on the source rock screening analysis such as TOC measurements, Rock-Eval pyrolysis and organic petrography) of hydrocarbons within the Kohat sub-basin (Meissner et al. 1974; Wandrey et al. 2004; Shah 2009; Rehman et al. 2009; Gardezi et al. 2017). The current research work is mainly focused on the source rock's screening as well as biomarkers analysis to provide information about the quality and type of organic matter and its thermal maturity as well as environment of deposition of the Early Cretaceous Chichali Formation within the Kohat sub-basin.

\section{Tectonic and geology of the area}

The collision of Indian and Eurasian plates during Cretaceous time has produced compressive tectonic structures on the north and northwest portion of the Indian tectonic plate (Abbasi and McElroy 1991). Since the Cretaceous time, the continuous pushing of the Indian plate created Himalayan orogenic belt with related chain of foreland basins (Wandrey et al. 2004). The Kohat sub-basin is an intricate compressional basin of Himalayan Foreland Belt (Fig. 1). The Main Boundary Thrust (MBT) and Surghar Range Thrust mark the northern and southern boundaries of this basin, respectively. The eastern and western boundaries of this basin are marked by Indus river and Kurram Fault, respectively. The Mesozoic sediments are thrust over Eocene-Miocene along MBT (Yeats and Hussain 1987). Along the Surghar Range Thrust, the Mesozoic sediments are thrust southward over the alluvium of the Punjab Foreland. The Mesozoic sediments are juxtaposing with Eocene-Miocene sediments along Kurram Fault (Ahmad 2003). Surghar Range which represents the leading deformational front of the Kohat sub-basin is separated from the Salt Range Thrust (SRT) by Kalabagh Strike-Slip Fault. The exposed sedimentary rocks (shales, 


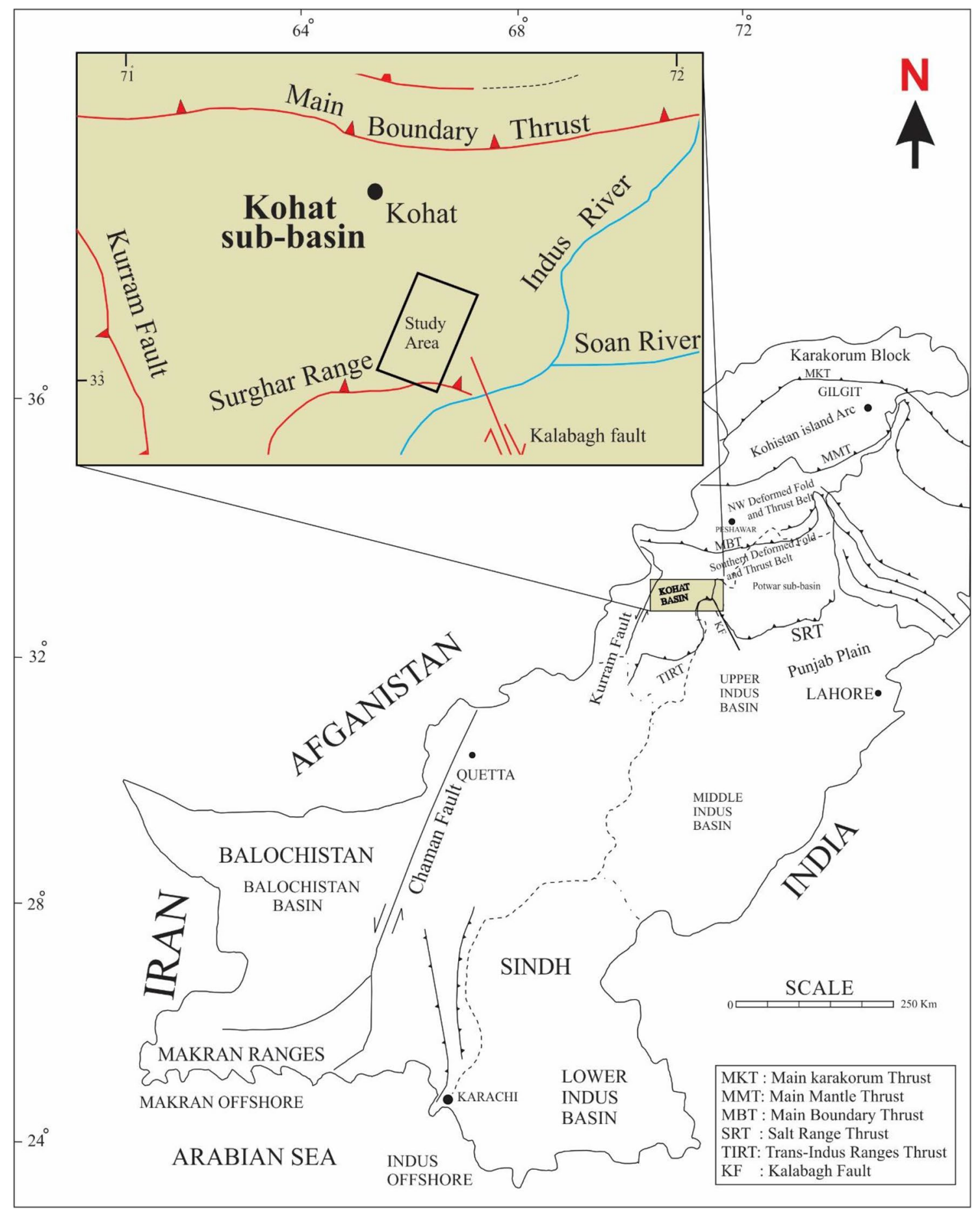

Fig. 1 Tectonic map of Pakistan showing the major tectonic features and the location of the study area (after Ahsan and Chaudhry 2008) 
Table 1 The generalized exposed stratigraphy of the Kohat sub-basin (after Kadri 1995)

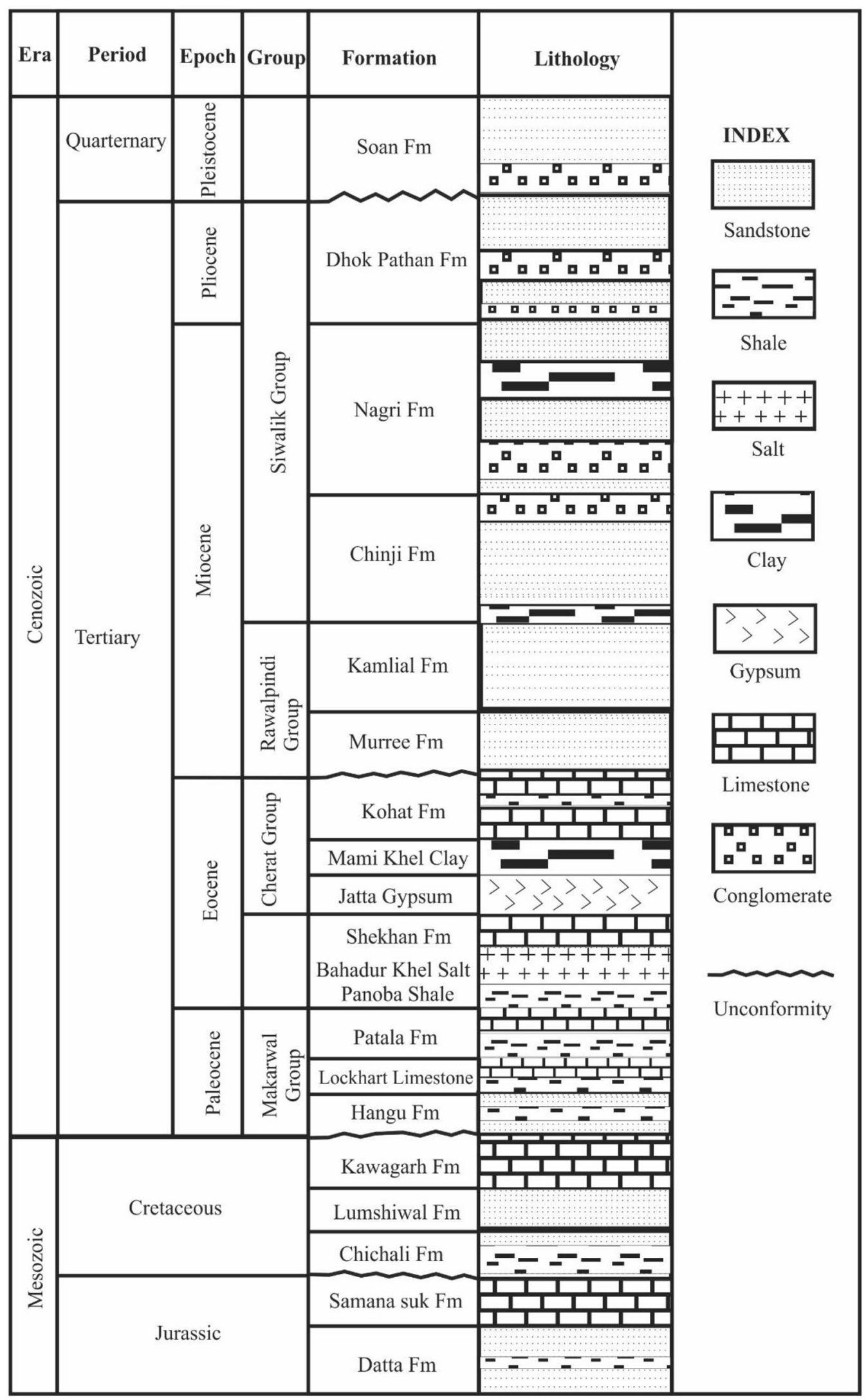


sandstones, limestones, gypsum, evaporates) of the Kohat sub-basin are ranging in age from Jurassic to Quaternary (Table 1).

\section{Methods and materials}

A total of 17 samples, seven from Chichali Nala section (Surghar Range) and 10 drill cuttings (from Mela-05 well of Mela oil field) of the Chichali Formation, were collected. The techniques performed included TOC, RE, organic petrography, column chromatography and GC-MS. The TOC was carried out for all the samples, and RE was performed for the drill cuttings. The biomarker analysis was applied on six samples, three outcrop samples from the Chichali Nala section and three drill cuttings from Mela-05 well. Four outcrop samples were also studied for macerals by the microscope.

The organic richness was measured by Carbon-Sulfur analyzer CS-580A (Helios). The Rock-Eval analysis was performed on Rock-Eval 6 instrument. Different Rock-Eval parameters and ratios such as $\mathrm{S}_{1}$ (free hydrocarbon at $300{ }^{\circ} \mathrm{C}$ ), $\mathrm{S}_{2}$ (hydrocarbons produced due to pyrolysis of kerogen), $\mathrm{S}_{3}\left(\mathrm{CO}, \mathrm{CO}_{2}\right.$ produced by the pyrolysis of the samples), oxygen index (OI: $\left.\mathrm{S}_{3} / \mathrm{TOC} \times 100\right)$, hydrogen index $\left(\mathrm{HI}: \mathrm{S}_{2} / \mathrm{TOC} \times 100\right)$, production index $\left(\mathrm{PI}: \mathrm{S}_{1} / \mathrm{S}_{1}+\mathrm{S}_{2}\right)$ and the $T_{\max }$ were used to determine the source rock potential of the Chichali Formation. The vitrinite reflectance measurement and macerals assessment was performed by Carl Zeiss Axio microscope. The Soxhlet apparatus was used to extract the bitumen through dichloromethane and methanol. The two components of bitumen, i.e., maltenes and asphaltenes, were separated from using n-pentane. Column chromatographic technique was used for the separation of saturates, aromatics and polar (resin) compounds present in maltene. The gas chromatograph mass spectrometer (GC-MS) was

Table 2 The TOC results of Mela-05 drill cuttings of the Chichali Formation

\begin{tabular}{lllll}
\hline S. no. & Sample ID & Depth $(\mathrm{m})$ & Sample type & TOC $(\mathrm{wt} \%)$ \\
\hline 1 & CF-1A & 4760 & Shale & 1.08 \\
2 & CF-2A & 4766 & Shale & 1.2 \\
3 & CF-3A & 4772 & Shale & 1.40 \\
4 & CF-4A & 4776 & Shale & 0.90 \\
5 & CF-5A & 4782 & Shale & 1.04 \\
6 & CF-6A & 4784 & Shale & 1.02 \\
7 & CF-7A & 4786 & Shale & 1.06 \\
8 & CF-8A & 4788 & Shale & 1.04 \\
9 & CF-9A & 4790 & Shale & 1.08 \\
10 & CF-10A & 4802 & Shale & 1.18 \\
\hline
\end{tabular}

Table 3 The TOC results of outcrop samples of the Chichali Formation

\begin{tabular}{llll}
\hline S. no. & Sample ID & Sample type & TOC (wt\%) \\
\hline 1 & CF-1B & Shale & 0.57 \\
2 & CF-2B & Shale & 0.43 \\
3 & CF-3B & Shale & 0.29 \\
4 & CF-4B & Shale & 0.55 \\
5 & CF-5B & Shale & 0.45 \\
6 & CF-6B & Shale & 0.53 \\
7 & CF-7B & Shale & 0.59 \\
\hline
\end{tabular}

used for the biomarkers study in saturate and aromatic fractions.

\section{Results and discussion}

\section{Source rock screening analysis}

\section{Total organic carbon (TOC)}

The TOC results of the drill cuttings and outcrop samples of Chichali Formation are presented in Table 2 and 3, respectively. The TOC in drill cuttings from the Mela-05 well ranges from 0.9 to $1.40 \mathrm{wt} \%$ (Fig. 2) representing fair to good hydrocarbon potential (Peters and Cassa 1994). The outcrop samples of the Chichali Formation show poor to fair potential of petroleum as the values of TOC are in the range of $0.29-0.59$ wt \% (Table 3). The low values of TOC in the outcrop samples are probably due to the effect of weathering of the organic constituents.

\section{Hydrocarbon potential and organic matter type}

The organic matter type in the source rock determines the types of hydrocarbon products in that source rock (Tissot and Welte 1984; Hunt 1979). The cross-plots of HI versus OI (Espitalié et al. 1977), HI versus $T_{\max }$ (Espitalié et al. 1986), TOC versus $S_{2}$ (Langford and Blanc-Valleron 1990) and the organic petrographic analysis were used for the assessment of the organic matter's type within the Chichali Formation.

The results acquired from the Rock-Eval of the Chichali Formation's drill cuttings are listed in Table 4. According to Van Krevelen (1984), the Chichali Formation has mainly type III kerogen at present time (Fig. 3a). The $T_{\max }$ versus hydrogen index cross-plot designates that all of the samples are present at the boundary of the oil-gas-prone zone and display type III kerogen at current time (Fig. 4a). The TOC versus $S_{2}$ cross-plot shows that almost all the samples of the Chichali Formation fall in gas-prone zone with type III kerogen at present time (Fig. 5).

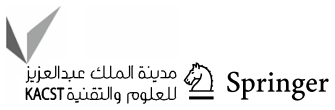




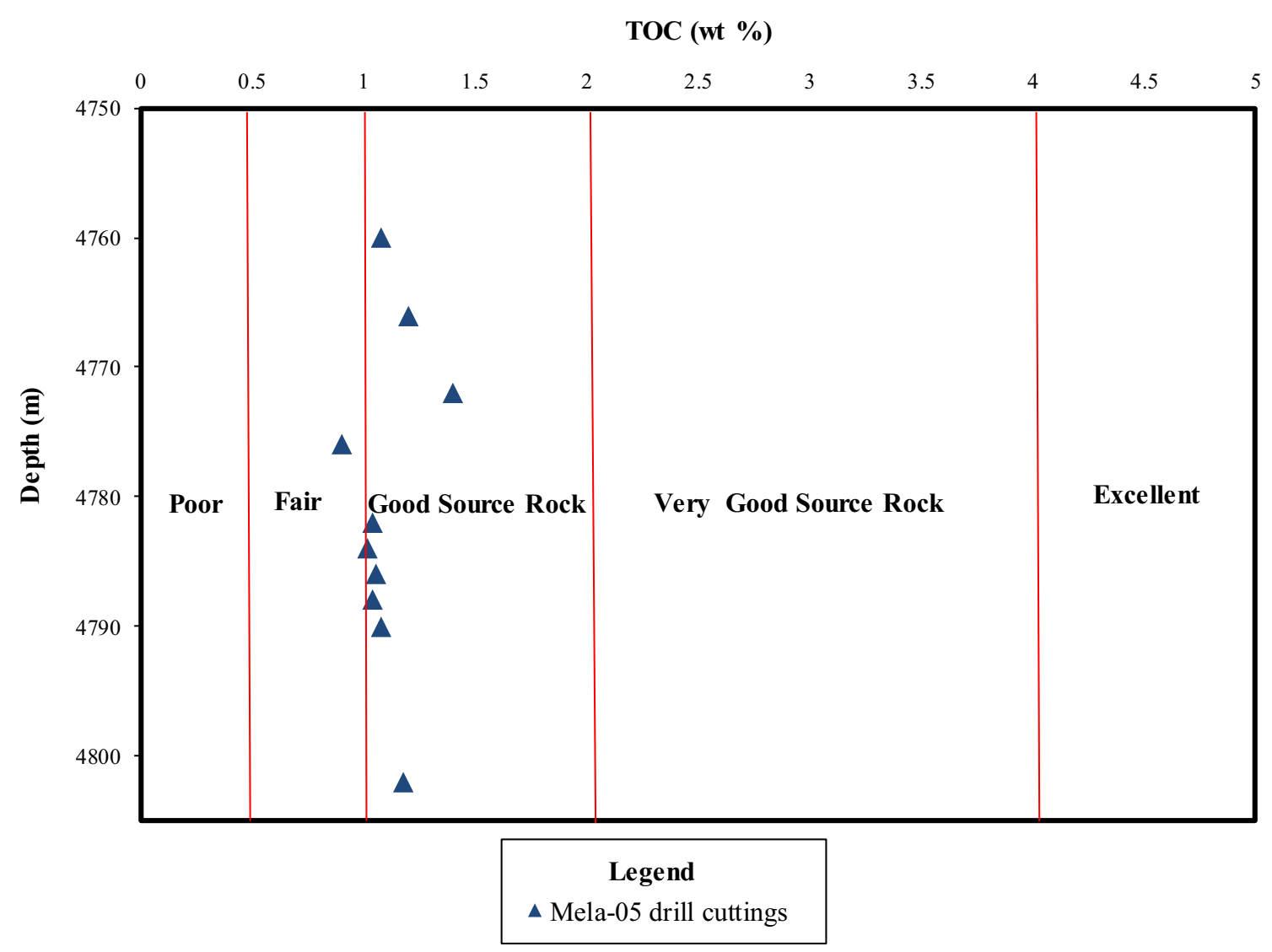

Fig. 2 The cross-plot of depth vs TOC, showing the distribution of TOC (wt \%) in the Mela-05 drill cuttings of the Chichali Formation

Table 4 Rock-Eval pyrolysis results of the Chichali Formation from Mela-05

\begin{tabular}{lllllllllll}
\hline S. no. & Sample ID & Sample depth & $\mathrm{S}_{1}$ & $\mathrm{~S}_{2}$ & $\mathrm{~S}_{3}$ & $\mathrm{OI}$ & $\mathrm{HI}$ & $\mathrm{HI}_{\mathrm{o}}$ & $T_{\max }$ & $\mathrm{PI}$ \\
\hline 1 & CF-1A & 4760 & 0.35 & 0.81 & 0.50 & 46 & 75 & 300 & 451 & 0.30 \\
2 & CF-2A & 4766 & 0.76 & 1.48 & 0.87 & 73 & 123 & 436 & 438 & 0.34 \\
3 & CF-3A & 4772 & 0.8 & 1.28 & 0.81 & 58 & 91 & 349 & 449 & 0.39 \\
4 & CF-4A & 4776 & 0.55 & 0.86 & 0.54 & 60 & 96 & 364 & 452 & 0.39 \\
5 & CF-5A & 4782 & 1.11 & 0.95 & 0.65 & 63 & 91 & 349 & 451 & 0.54 \\
6 & CF-6A & 4784 & 0.99 & 0.98 & 0.78 & 77 & 96 & 364 & 448 & 0.50 \\
7 & CF-7A & 4786 & 0.92 & 1 & 0.65 & 61 & 94 & 358 & 451 & 0.48 \\
8 & CF-8A & 4788 & 0.84 & 0.95 & 0.62 & 60 & 91 & 349 & 452 & 0.46 \\
9 & CF-9A & 4790 & 0.82 & 0.99 & 0.68 & 63 & 92 & 352 & 453 & 0.45 \\
10 & CF-10A & 4802 & 1.16 & 1.18 & 0.81 & 69 & 100 & 375 & 447 & 0.51 \\
\hline
\end{tabular}

However, the cross-plots of original hydrogen index $\left(\mathrm{HI}_{\mathrm{o}}\right)$ (calculated, using ZetaWare software; https://www.zetaw are.com/utilities/srp/index.html) against OI (Fig. 3b) and $T_{\max }$ (Fig. 4b) indicate type II kerogen formation during the deposition of Chichali Formation. It is also evident from compositional analysis of macerals where major macerals are liptinite derived from marine organic source (Table 5).

\section{Thermal maturity of the organic matter}

The organic matter thermal maturation level was assessed through $T_{\max }$, PI and vitrinite reflectance. All the drill cuttings from the Mela-05 well show peak to late thermal maturity stage based on the $T_{\max }$ and production index values (Fig. 6, Table 4). 


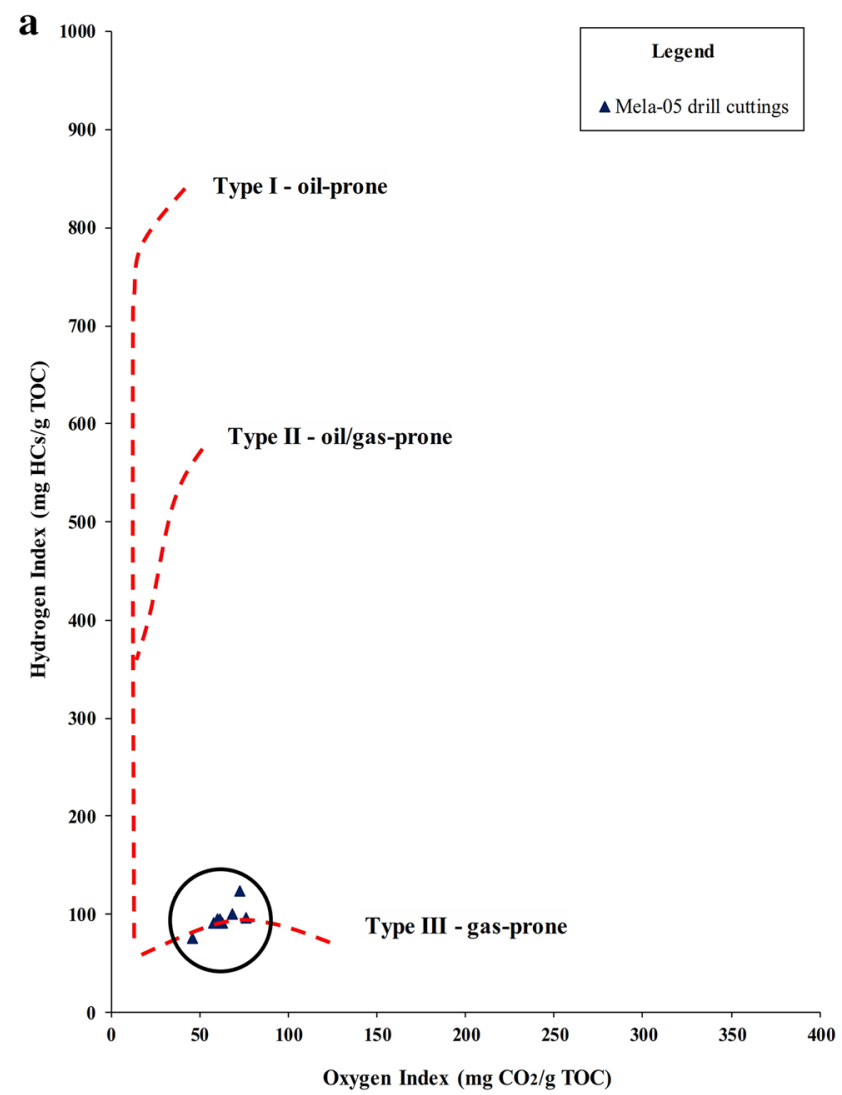

Fig. 3 a The HI versus OI cross-plot (modified after Van Krevelen Diagram), showing the present kerogen type in the Mela-05 drill cuttings of the Chichali Formation (after Espitalié et al. 1977). b The

The Chichali Formation's outcrop samples have vitrinite reflectance (Ro) values in the range of $0.76-0.84$ (Table 5), show thermal maturity in the oil window phase and have not reached peak oil production phase $(>0.9 \%$ Ro).

\section{Biomarkers: Environmental conditions and organic matter input}

\section{n-alkanes and isoprenoids distribution}

The terrigenous-to-aquatic ratio (TAR) determines the relative amount of the terrestrial versus marine organic matter (Bourbonniere and Meyers 1996). The Chichali Formation's drill cuttings obtained from Mela-05 well have TAR values in the range of $0.08-0.18$ signifying more algal organic matter input as compared to vascular plants (Fig. 7, Table 6). The same comparable tendency is shown by the n-alkanes chromatograms of the Chichali Formation's outcrop samples

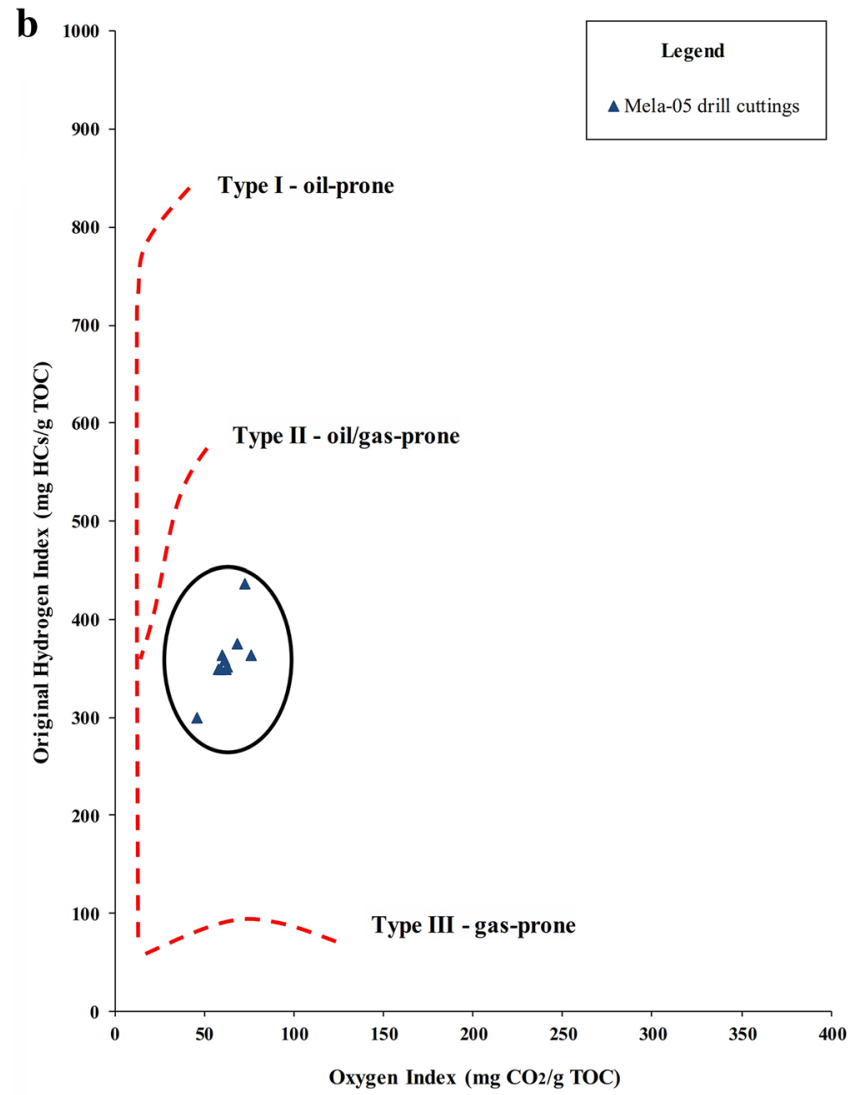

$\mathrm{HI}_{\mathrm{o}}$ versus OI cross-plot (modified after Van Krevelen Diagram), showing the original kerogen type in the Mela-05 drill cuttings of the Chichali Formation (after Espitalié et al. 1977)

where short-chain n-alkanes have more concentration compared to long-chain n-alkanes (Fig. 7).

Pristane and phytane are the acyclic isoprenoid compounds present in the source rock extracts and crude oils. The most abundant source of pristane and phytane is the phototrophic organisms and purple sulfur bacteria (Brooks et al. 1969; Powell and McKirdy 1973). In oxic environment, the decarboxylation within the side chain of phytyl yields pristane (Pr), while in the anoxic environment dehydration and reduction within the phytyl side chain yield phytane (Ph) (Didyk et al. 1978; Powell and McKirdy 1973). The Chichali Formation's samples (drill cutting as well as the outcrop samples) have $\mathrm{Pr} / \mathrm{Ph}$ ratios less than $1(\mathrm{Pr} / \mathrm{Ph}<1)$ and indicate anoxic environment of deposition (Table 6).

A cross-plot of phytane $/ \mathrm{nC}_{18}$ versus pristane $/ \mathrm{nC}_{17}$ shows that Chichali Formation samples (outcrop samples and drill cuttings) have more marine organic input (Fig. 8).

\section{Terpanes and steranes distribution}

The low ratios of the $\mathrm{C}_{19} / \mathrm{C}_{23}$ TCT and $\mathrm{C}_{20} / \mathrm{C}_{23}$ TCT in the studied Chichali Formation's samples indicate marine 


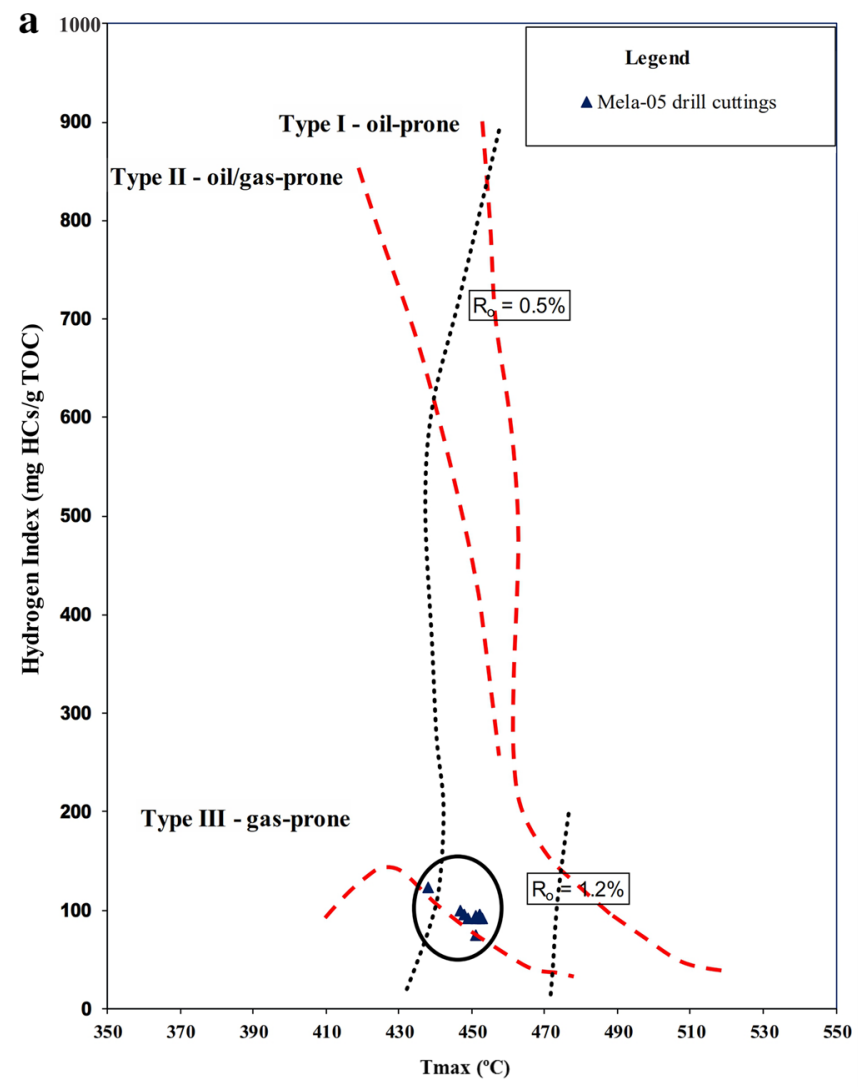

Fig. 4 a The HI versus $T_{\max }$ cross-plot, showing present kerogen type in Mel-05 drill cuttings of the Chichali Formation (after Espitalié et al. 1986). b The $\mathrm{HI}_{\mathrm{o}}$ versus $T_{\max }$ cross-plot, showing original

organic source (Fig. 9, Table 7) (Hao et al. 2010). Similarly, the low values of $\mathrm{C}_{26} / \mathrm{C}_{25}$ TCT ratios in the Chichali Formation's outcrop samples indicate marine depositional environment (Fig. 9, Table 7). The lack of gammacerane in the Chichali Formation's outcrop samples depicts nonhypersaline environment at the time of organic matter deposition and is supported with low $\mathrm{C}_{26} / \mathrm{C}_{25}$ ratios. The Chichali Formation's outcrop samples have high tricyclic terpanes-to-hopanes $(\mathrm{TCT} / \mathrm{H})$ ratios, indicating higher algal input (Table 7, Fig. 9). Similar trend is shown by the ratios of $\mathrm{C}_{23}$ tricyclic terpane to hopane $\left(\mathrm{C}_{23} \mathrm{TCT} / \mathrm{H}\right.$; Table 7$)$. The absence of terrestrial biomarker (oleanane) also justifies marine environment of deposition for Chichali Formation. However, no terpanes were identified in drill cuttings from Chichali Formation of Mela-05 well (Fig. 9). The lack of terpanes and low concentration of long-chain n-alkanes suggest high thermal maturity of the drill cuttings which is in conjunction with thermal maturity determined by the $T_{\max }$ and production index values (Fig. 6).

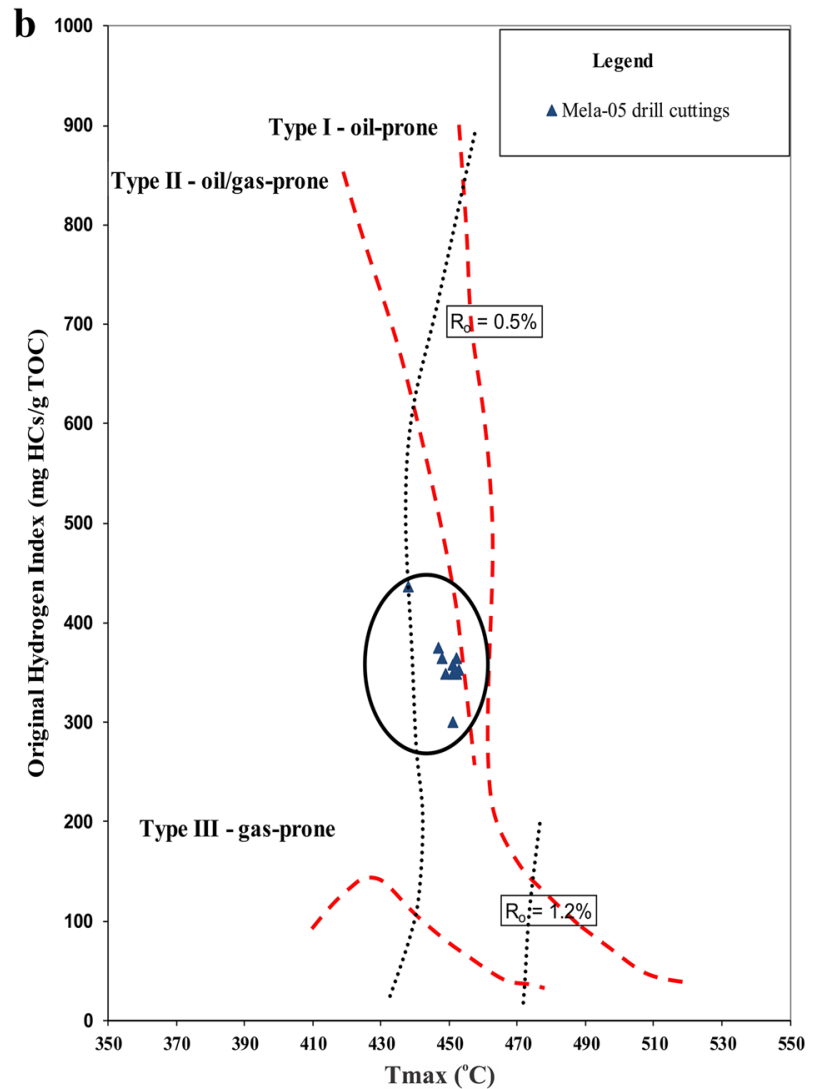

kerogen type in Mel-05 drill cuttings of the Chichali Formation (after Espitalié et al., 1986)

The abundance of different steranes can also point toward marine or terrestrial nature of the organic matter (Peters et al. 2005). The higher values of $\mathrm{C}_{27}$ steranes compared to $\mathrm{C}_{29}$ steranes in the Chichali Formation's outcrop samples indicate marine algal origin for the organic matter (Figs. 10, 11, Table 7). The steranes were not identified in the extracts of Mela-05 drill cuttings of the Chichali Formation, probably due to higher thermal cracking of the organic matter (Fig. 10).

\section{Aromatic compounds distribution}

The source rock paleo-environment and lithology can be determined through the cross-plot of dibenzothiophene-tophenantrene versus Pr-to-Ph ratios (Hughes et al. 1995).

The Chichali Formation's samples (outcrop samples and drill cuttings) fall in Zone 2, depicting anoxic sulfate poor depositional environment with mixed shale and carbonate lithology (Fig. 12). 


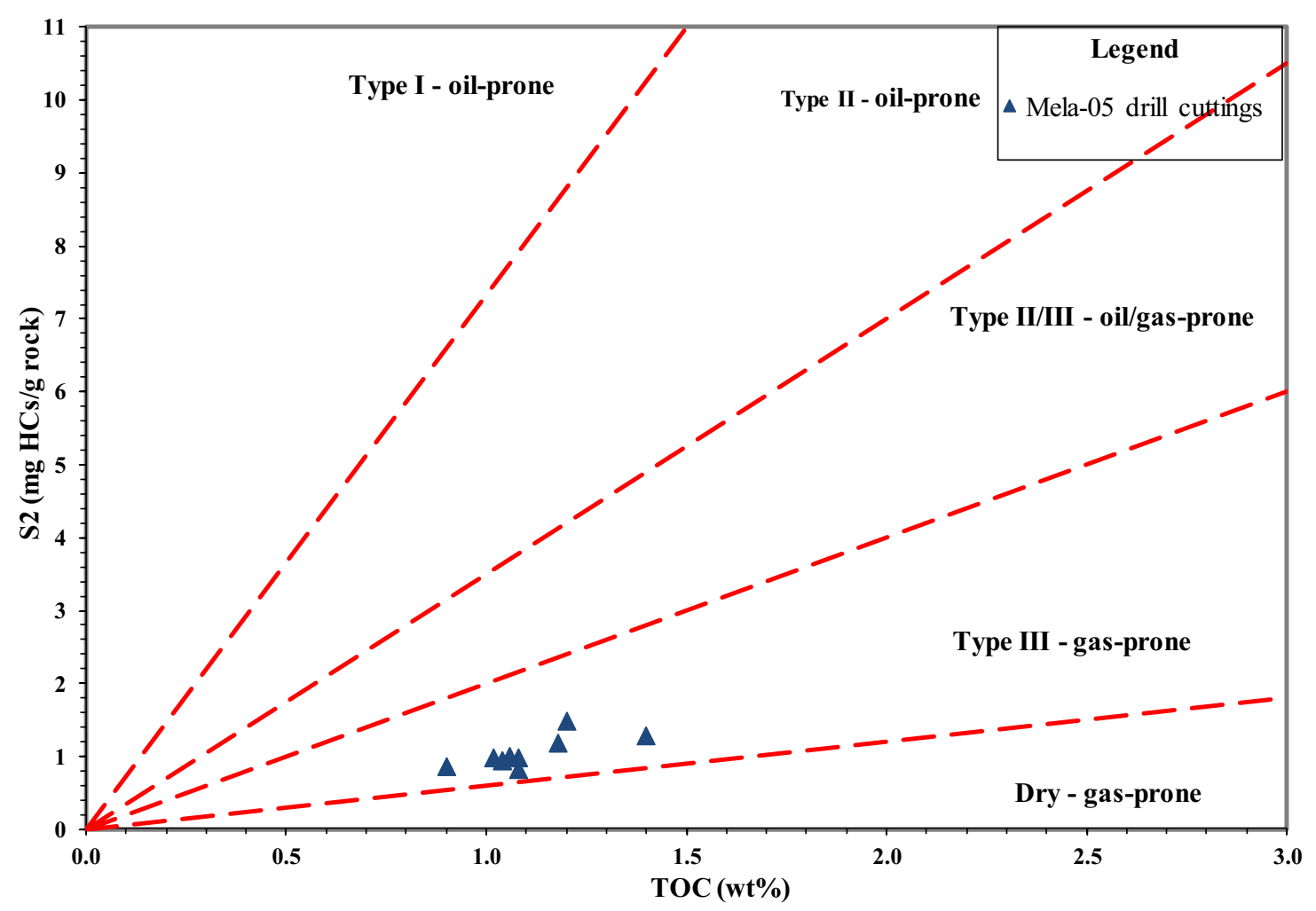

Fig. 5 The $S_{2}$ versus TOC cross-plot, showing the current kerogen type in the Mela-05 drill cuttings of the Chichali Formation (after Langford and Blanc-Valleron 1990)

\section{Biomarkers: thermal maturity}

To evaluate the organic matter thermal maturity level, different saturate and aromatic compound's ratios of Chichali Formation's extracts were used in this research work. The results of column chromatography reveal that saturates (SAT)-to-aromatics (ARO) ratios are higher $(>1.49)$ for the Chichali Formation, indicating mature organic matter (Table 6) (Tissot and Welte 1984). Similarly, the carbon preference index (CPI) values or odd-to-even predominance (OEP) values are nearly equal to 1 ; homohopane ratios $\left[\mathrm{C}_{31}\right.$ $22 \mathrm{~S} /(22 \mathrm{~S}+22 \mathrm{R})]$ ranging from 0.47 to 0.58 and $\mathrm{C}_{29} \beta \beta /$ $\alpha \alpha+\beta \beta$ sterane isomer ratios ranging from 0.56 to 0.65 for the Chichali Formation confirm thermally mature nature of the organic matter (Tables 6, 8).

The isomerization ratio of $\mathrm{C}_{29}$ steranes $\left[\mathrm{C}_{29}\right.$ 20S/ $(20 \mathrm{~S}+20 \mathrm{R})]$ in the Chichali Formation's outcrop samples is in the range of 0.46 to 0.51 , indicating thermally mature organic matter and thus pointing to the oil generation phase (Table 8).

The calculated vitrinite reflectance $\left(V R_{c}\right)$ derived from methyl-phenanthrene index (MPI-1) has values in the range of $0.77-0.85$ for outcrop samples and 0.90-0.94 for Mela05 drill cuttings. The Chichali Formation's outcrop samples
Table 5 Organic petrographic results of samples from Chichali Formation

\begin{tabular}{llllll}
\hline Sample ID & Observations & Vitrinite & Liptinite & $\begin{array}{l}\text { Quantities } \\
\text { of Liptinite }\end{array}$ & $\%$ Ro \\
\hline CF-1B & 10 & O & X & 4 & 0.76 \\
CF-4B & 9 & O & X & 4 & 0.78 \\
CF-6B & 24 & O & X & 4 & 0.84 \\
CF-7B & 13 & O & X & 3 & 0.80 \\
\hline
\end{tabular}

The relative abundance is described by $(\mathrm{O}=5-<20 \%, \mathrm{X}=>50 \%)$, organic matter; $3=$ common, $4=$ abundant

indicate comparatively low thermal maturity, based on $V R_{c}$, whereas the Chichali Formation's drilled cuttings have $V R_{c}$ values greater than 0.9 and show postmature stage for the generation of hydrocarbons (Figs. 13, 14, Table 8).

Similarly, the calculated vitrinite reflectance $\left(V R_{m}\right)$ values based on methyl-dibenzothiophene ratio (MDR) also indicate low thermal maturity of the outcrop samples compared to drill cuttings (Figs. 13, 14, Table 8). 

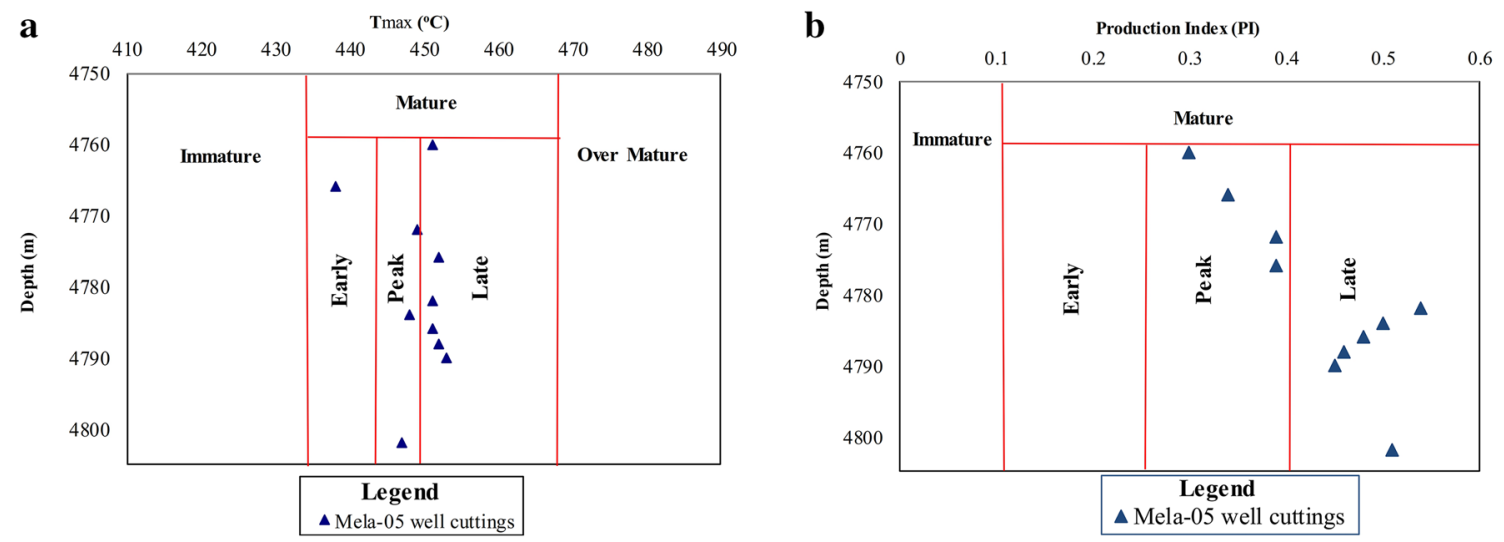

Fig. 6 The organic matter's thermal maturity within drill cuttings of Chichali Formation using a depth versus $T_{\max }$ and $\mathbf{b}$ depth versus PI crossplots (after Peters and Cassa 1994)

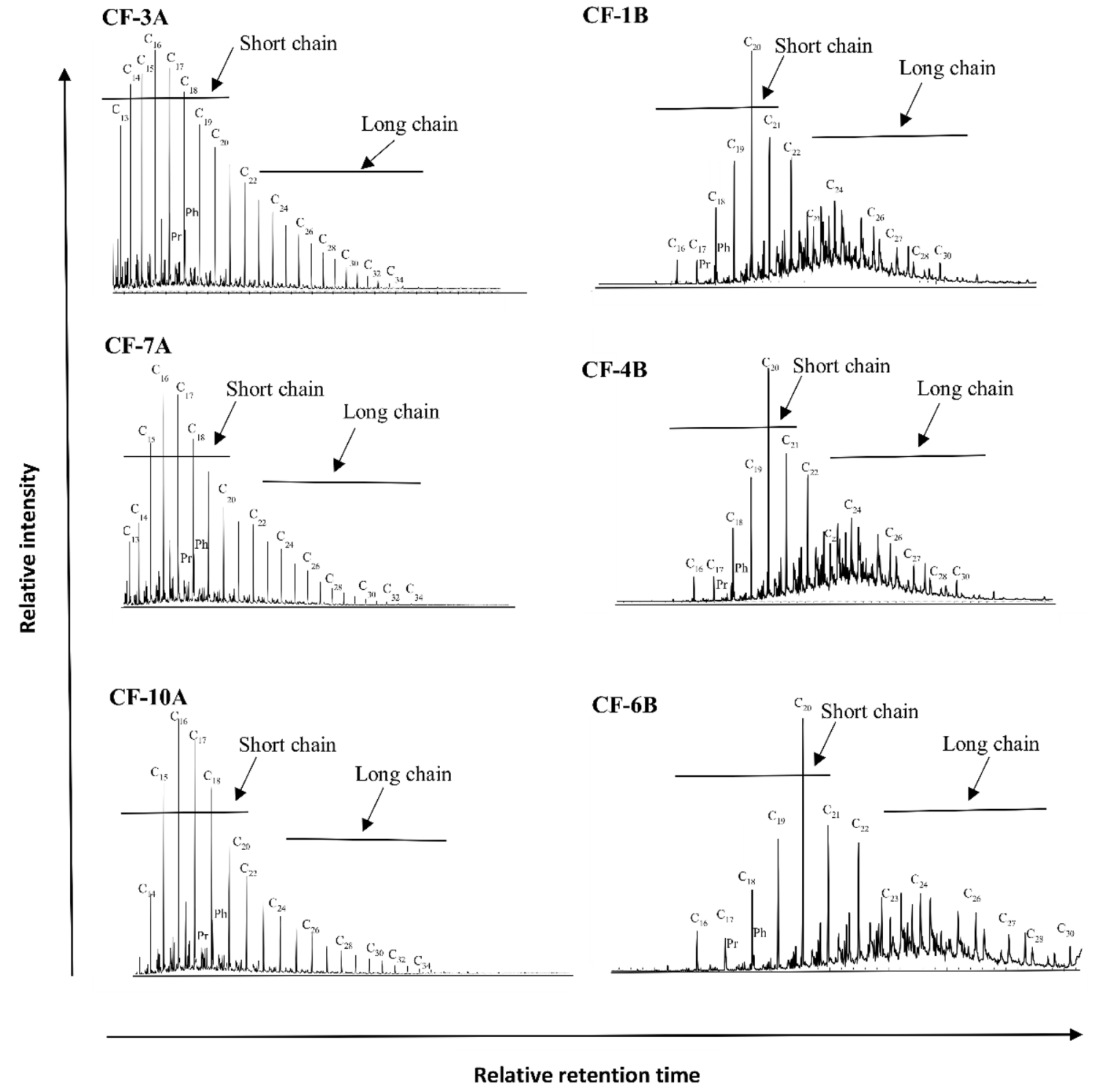

Fig. $7 \mathrm{~m} / \mathrm{z} 57$ chromatograms of Mela-05 drill cuttings (left) and outcrop samples (right) showing distribution of n-alkanes and isoprenoids 
Table 6 The molecular composition as well as geochemical parameters based on n-alkanes and isoprenoid of the Chichali Formation

\begin{tabular}{llllllllllll}
\hline Sample ID & Type & Saturate $(\%)$ & Aromatic $(\%)$ & Resin $(\%)$ & SAT/ARO & TAR & CPI & OEP-1 & Pr/Ph & Pr/nC17 & Ph/nC18 \\
\hline CF-3A & Cuttings & 45.30 & 30.21 & 24.49 & 1.49 & 0.18 & 1.1 & 0.98 & 0.54 & 0.25 & 0.37 \\
CF-7A & Cuttings & 46.73 & 23.09 & 30.18 & 2.02 & 0.10 & 1.1 & 1.1 & 0.39 & 0.35 & 0.37 \\
CF-10A & Cuttings & 53 & 20.63 & 26.35 & 2.57 & 0.08 & 1.0 & 1 & 0.34 & 0.28 & 0.43 \\
CF-1B & Outcrop & 51.10 & 30.75 & 18.15 & 1.66 & nd & nd & 0.98 & 0.69 & 0.52 & 0.76 \\
CF-4B & Outcrop & 55.62 & 24.07 & 20.21 & 2.31 & nd & nd & 0.96 & 0.64 & 0.45 & 0.78 \\
CF-6B & Outcrop & 56.79 & 24 & 19.20 & 2.36 & nd & nd & 0.99 & 0.63 & 0.56 & 0.70 \\
\hline
\end{tabular}

$T A R=\left(\mathrm{nC}_{27}+\mathrm{nC}_{29}+\mathrm{nC}_{31}\right) /\left(\mathrm{nC}_{15}+\mathrm{nC}_{17}+\mathrm{nC}_{19}\right), C P I=1 / 2\left[\left(\mathrm{C}_{25}+\mathrm{C}_{27}+\mathrm{C}_{29}+\mathrm{C}_{31}+\mathrm{C}_{33} / \mathrm{C}_{24}+\mathrm{C}_{26}+\mathrm{C}_{28}+\mathrm{C}_{30}+\mathrm{C}_{32}\right)+\left(\mathrm{C}_{25}+\mathrm{C}_{27}+\mathrm{C}_{29}+\mathrm{C}_{31}+\mathrm{C}_{33} /\right.\right.$ $\left.\left.\mathrm{C}_{26}+\mathrm{C}_{28}+\mathrm{C}_{30}+\mathrm{C}_{32}+\mathrm{C}_{34}\right)\right]$, OEP-1 $=\left(\mathrm{C}_{21}+6 \mathrm{C}_{23}+\mathrm{C}_{25}\right) /\left(4 \mathrm{C}_{22}+4 \mathrm{C}_{24}\right)$, nd = not determined
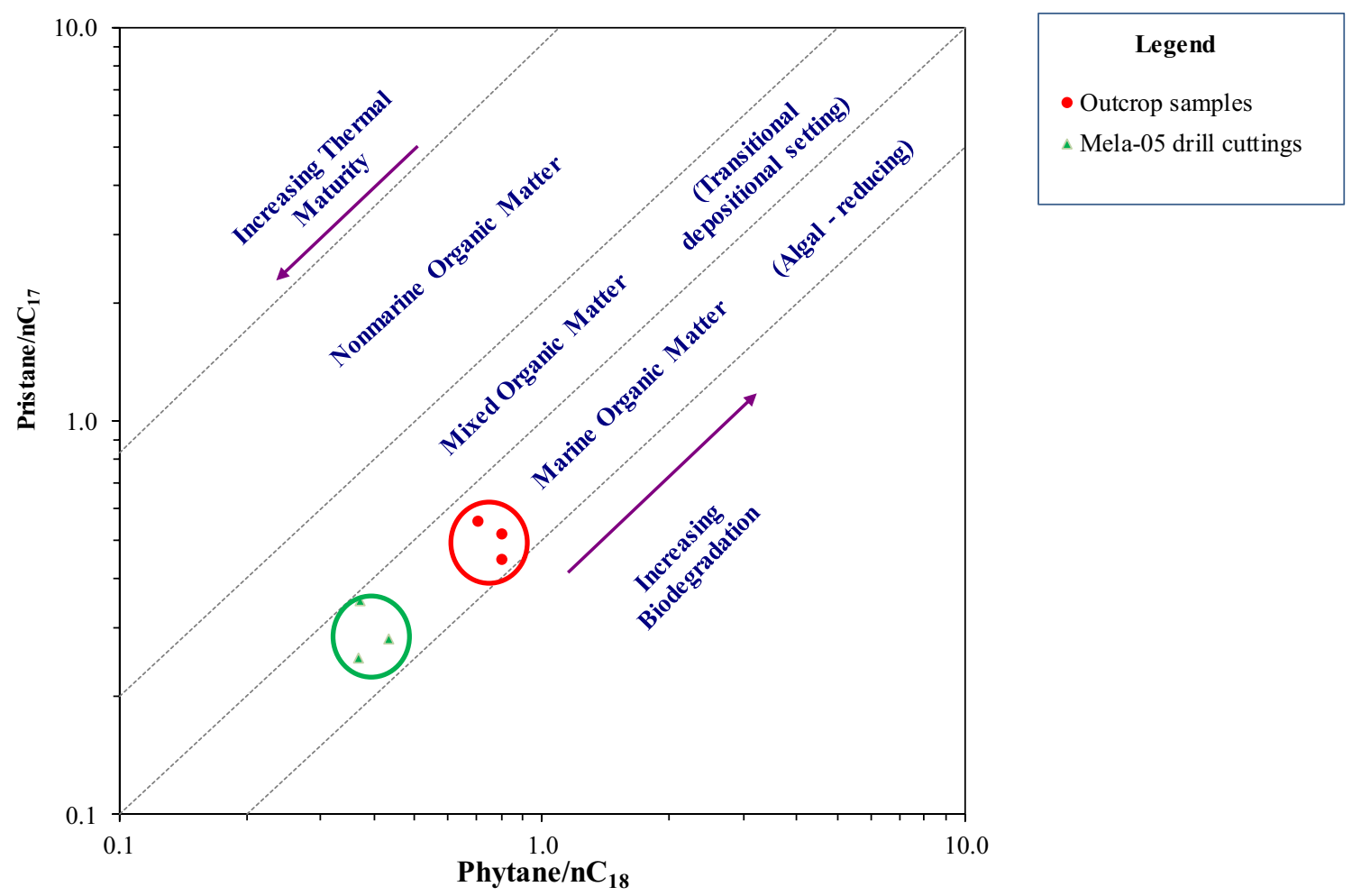

Fig. 8 The cross-plot of $\mathrm{Ph} / \mathrm{nC}_{18}$ versus $\mathrm{Pr} / \mathrm{nC}_{17}$ indicates the environment of deposition, source input and thermal maturation level of the samples (after Shanmugam 1985)

\section{Conclusions}

The Rock-Eval data indicate the type III kerogen at present time and has the potential to generate gas. The vitrinite reflectance values, $\mathrm{C}_{31} 22 \mathrm{~S} /(22 \mathrm{~S}+22 \mathrm{R})$ homohopane ratios, $\mathrm{C}_{29}$ sterane isomerization ratios, MPI-based calculated vitrinite reflectance values $\left(V R_{c}\right)$ and DMR-based calculated vitrinite reflectance values $\left(V R_{m}\right)$ indicate oil window phase of the outcrop samples of the Chichali Formation. The production index values, $T_{\max }$ values, MPI-based calculated vitrinite reflectance values $\left(V R_{c}\right)$ and DMR-based calculated vitrinite reflectance values $\left(V R_{m}\right)$ indicate gas window phase of the drill cuttings of Chichali Formation. The high thermal maturity of the drill cuttings compared to outcrop samples is also evident from the cross-plot of isoprenoids vs n-alkanes and absence of saturate biomarkers (terpanes, steranes) in the drill cuttings. All these geochemical parameters of thermal maturity for outcrop samples indicate that the Chichali Formation was already in oil window phase during the uplift of the Surghar Range, while the Chichali Formation (drill cuttings) in Kohat sub-basin had been overburdened later on and, therefore, entered into post-oil window phase and cracking of hydrocarbons that probably leads to condensate and gas formation in the Kohat sub-basin. The cross-plots of 


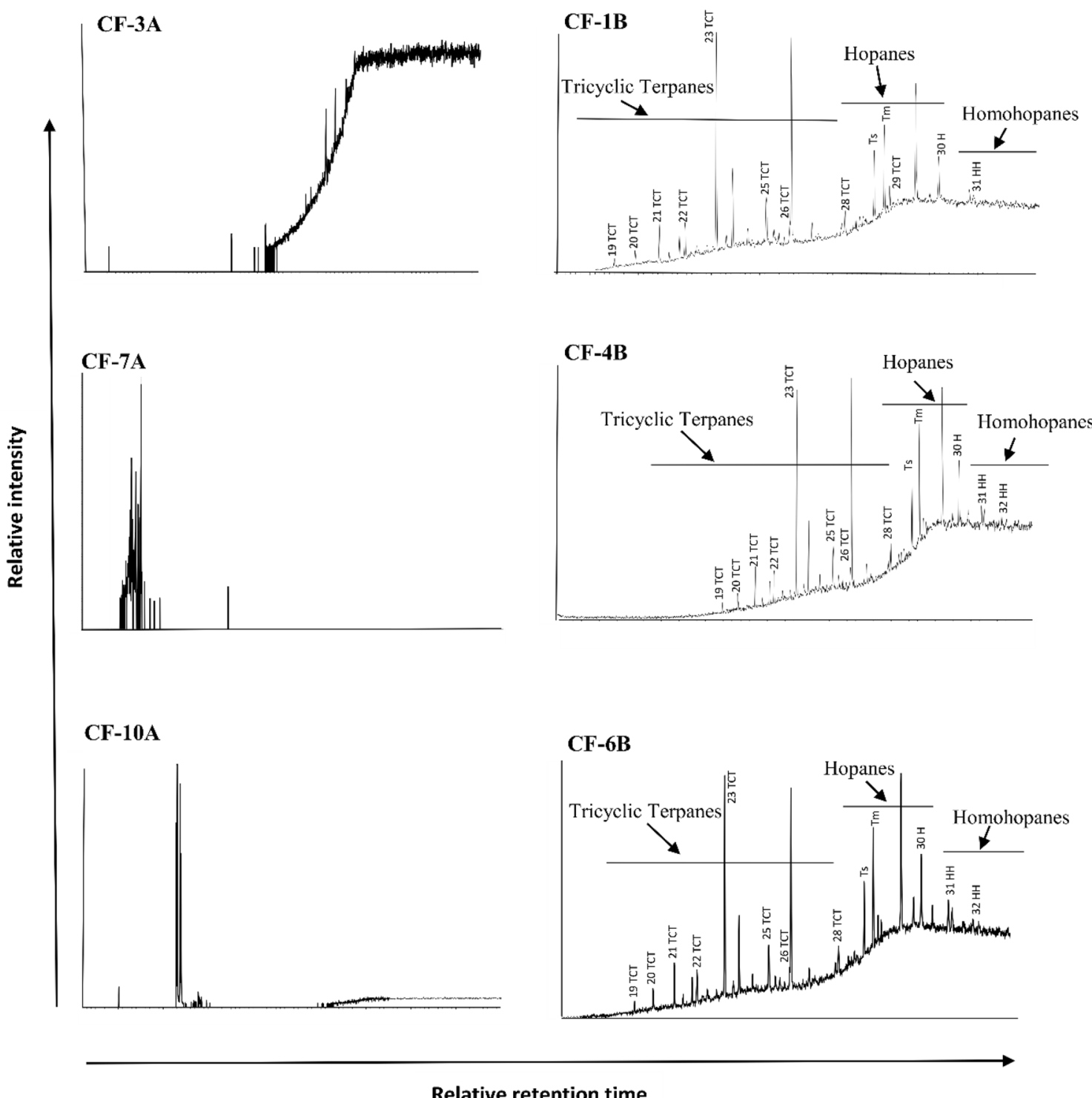

Fig. $9 \mathrm{~m} / \mathrm{z} 191$ chromatograms of Mela-05 drill cuttings (left) and outcrop samples (right) showing distribution of TCT and hopanes

Table 7 Terpane and sterane biomarker parameters used in this study

\begin{tabular}{|c|c|c|c|c|c|c|c|c|c|}
\hline \multirow[t]{2}{*}{ Sample ID } & \multicolumn{5}{|l|}{ Terpanes } & \multicolumn{3}{|c|}{ Steranes (\%) } & \multirow[t]{2}{*}{$\mathrm{C}_{29} / \mathrm{C}_{27}$ Sterane } \\
\hline & $\mathrm{C}_{19} / \mathrm{C}_{23} \mathrm{TCT}$ & $\mathrm{C}_{20} / \mathrm{C}_{23} \mathrm{CT}$ & $\mathrm{C}_{26} / \mathrm{C}_{25} \mathrm{TCT}$ & $\mathrm{TCT} / \mathrm{H}$ & $\mathrm{C}_{23} \mathrm{TCT} / \mathrm{H}$ & $\mathrm{C}_{27}$ & $\mathrm{C}_{28}$ & $\mathrm{C}_{29}$ & \\
\hline $\mathrm{CF}-1 \mathrm{~B}$ & 0.02 & 0.07 & 0.62 & 10.51 & 4.63 & 55 & 25 & 20 & 0.36 \\
\hline CF-4B & 0.03 & 0.09 & 0.29 & 6.99 & 2.51 & 54 & 25 & 20 & 0.37 \\
\hline CF-6B & 0.03 & 0.08 & 0.16 & 6.40 & 2.66 & 51 & 30 & 19 & 0.37 \\
\hline
\end{tabular}

OI versus $\mathrm{HI}_{\mathrm{o}}$ and $\mathrm{HI}_{\mathrm{o}}$ versus $T_{\max }$ indicate that the original kerogen was type II. The low percentage of vitrinite macerals $(<20 \%)$ and high quantity of liptinite macerals indicate a marine organic input for the Chichali Formation. The extracts of Chichali Formation have algal/marine organic matter (type II kerogen) that was deposited in anoxic environment. Marine input as well as anoxic environment is also evident from the presence of high abundance of short-chain 


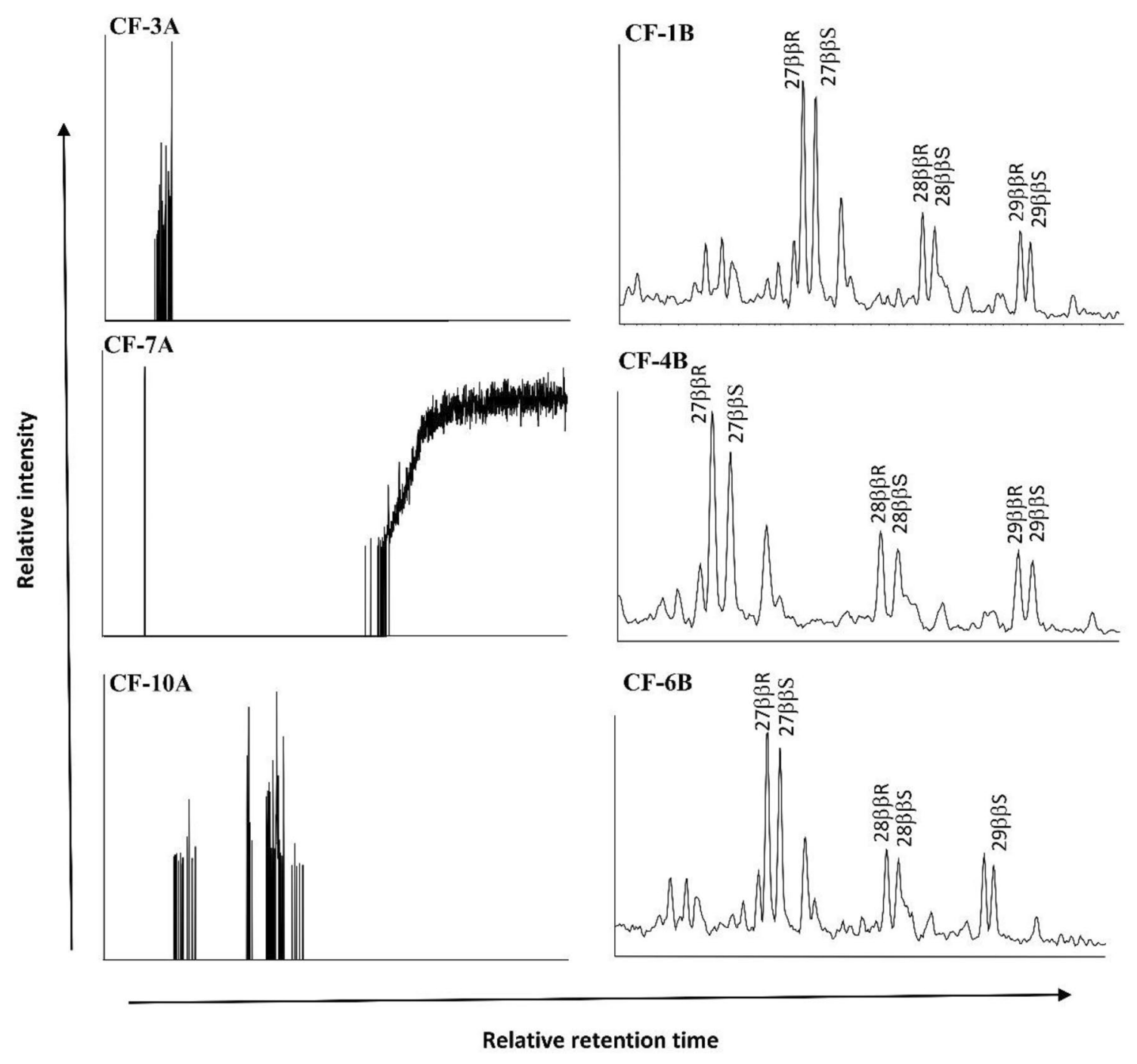

Fig. $10 \mathrm{~m} / \mathrm{z} 218$ chromatograms of Mela-05 drill cuttings (left) and outcrop samples (right) showing distribution of steranes

Fig. 11 The $\mathrm{Pr} / \mathrm{Ph}$ ratio versus $\mathrm{C}_{29} / \mathrm{C}_{27}$ steranes ratio cross-plot provides information about the environment of deposition and type of organic input (after Peters et al. 2005)

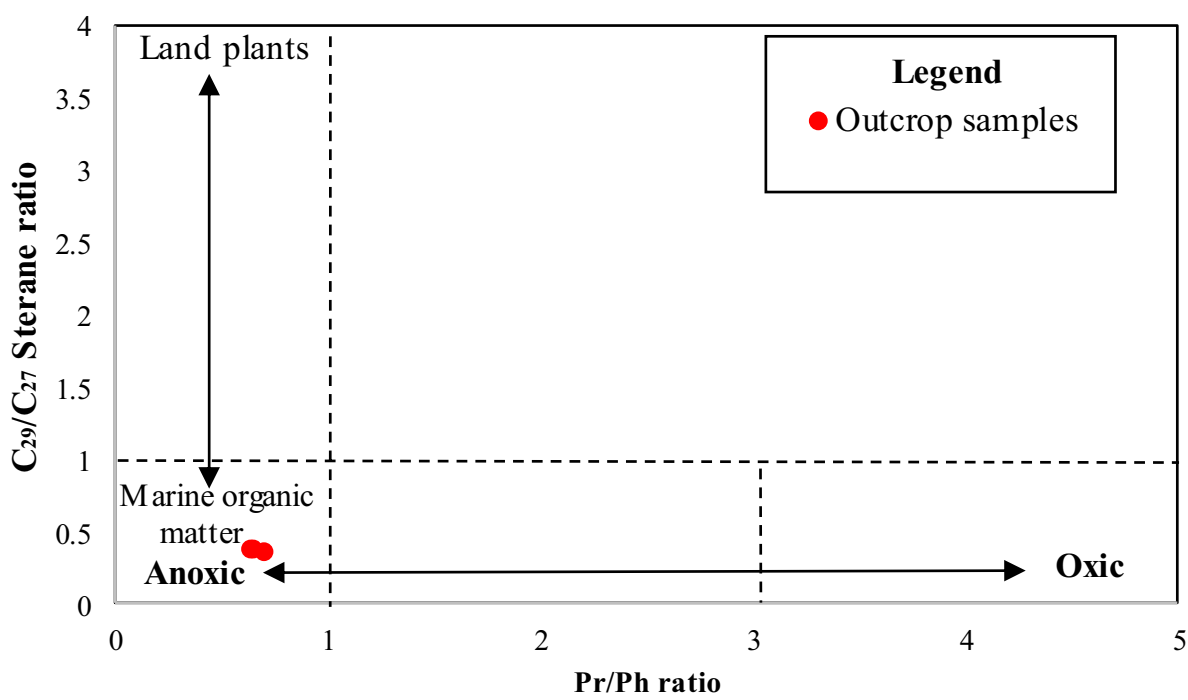

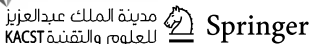


Fig. 12 The $\mathrm{Pr} / \mathrm{Ph}$ versus DBT/P cross-plot of the drill cuttings and outcrop samples of the Chichali Formation (after Hughes et al. 1995)

Table 8 Thermal maturity and environment of deposition parameters based on saturate and aromatic hydrocarbons in the Chichali Formation

Fig. 13 The VRc\% versus VRm\% cross-plot, showing the maturity difference in the drill cuttings and outcrop samples of the Chichali Formation

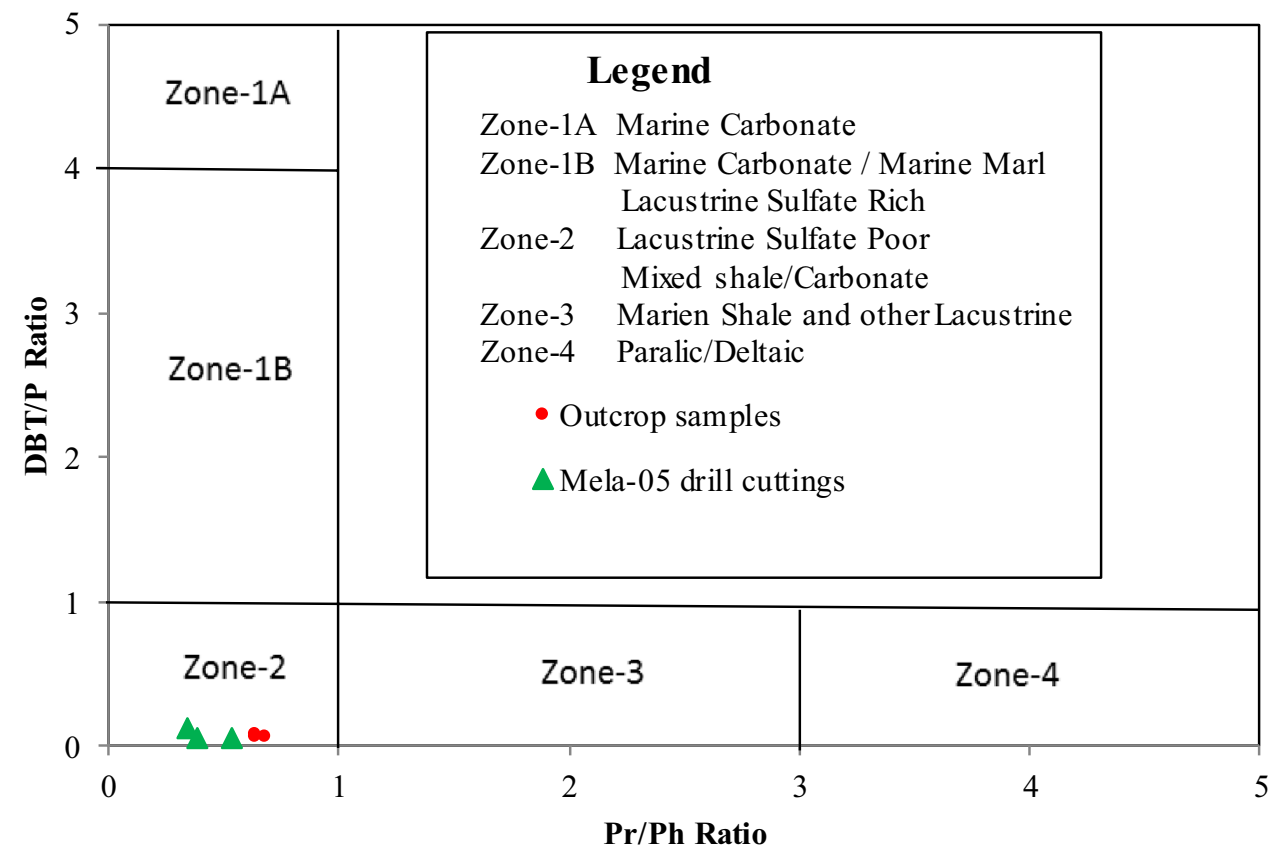

\begin{tabular}{lllllllll}
\hline Sample ID & $\begin{array}{l}\mathrm{S} /(\mathrm{S}+\mathrm{R}) \\
\mathrm{C}_{31} \text { Homohopane }\end{array}$ & $\begin{array}{l}\mathrm{C}_{29} \mathrm{~S} / \\
(\mathrm{S}+\mathrm{R}) \\
\text { sterane }\end{array}$ & $\begin{array}{l}\mathrm{C}_{29} \beta \beta / \\
\alpha \alpha+\beta \beta \\
\text { sterane }\end{array}$ & MPI-1 & VRc(\%) & MDR & VRm(\%) & DBT/P \\
\hline CF-1B & 0.47 & 0.46 & 0.56 & 0.62 & 0.77 & 2.23 & 0.67 & 0.05 \\
CF-4B & 0.52 & 0.51 & 0.65 & 0.79 & 0.87 & 2.15 & 0.67 & 0.05 \\
CF-6B & 0.58 & 0.47 & 0.65 & 0.74 & 0.85 & 1.73 & 0.64 & 0.07 \\
CF-3A & Absent & Absent & Absent & 0.83 & 0.90 & 4.97 & 0.87 & 0.06 \\
CF-7A & Absent & Absent & Absent & 0.86 & 0.92 & 4.59 & 0.85 & 0.05 \\
CF-10A & Absent & Absent & Absent & 0.90 & 0.94 & 5.52 & 0.91 & 0.12 \\
\hline
\end{tabular}

$M P I-1=\{1.5 \times[3-\mathrm{MP}+2-\mathrm{MP}] /[\mathrm{P}+1-\mathrm{MP}+9-\mathrm{MP}]\}, \quad V R c=(0.6 \times \mathrm{MPI}-1+0.4), \quad \mathrm{MDR}=4-\mathrm{MDBT} / 1-$ MDBT, $V R m=0.073 \times \mathrm{MDR}+0.51$

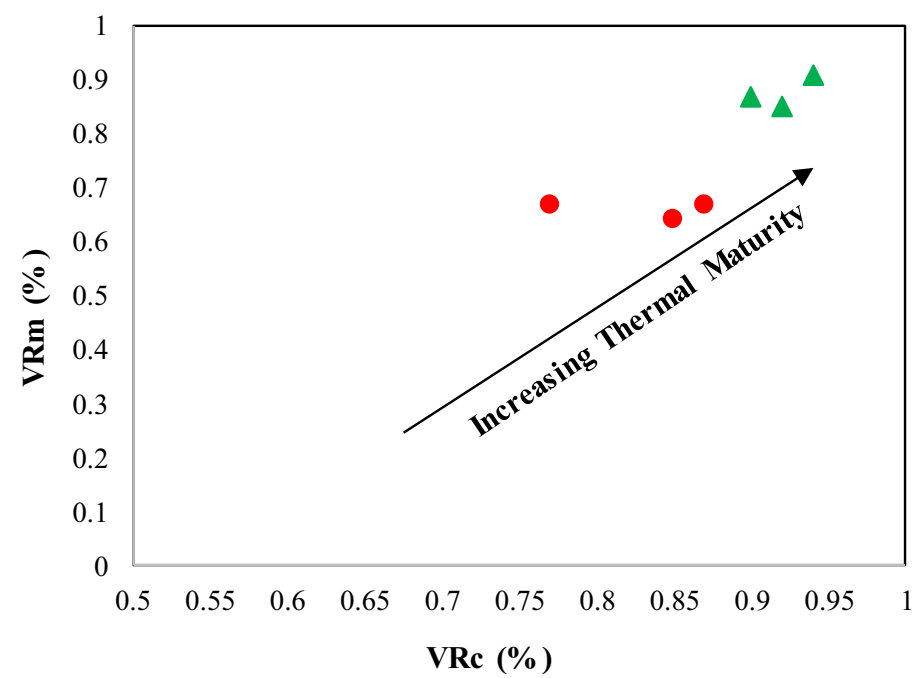

\section{Legend}

- Outcrop samples

$\Delta$ Mela-05 drill cuttings 


\section{Well Sample(CF-3A)}

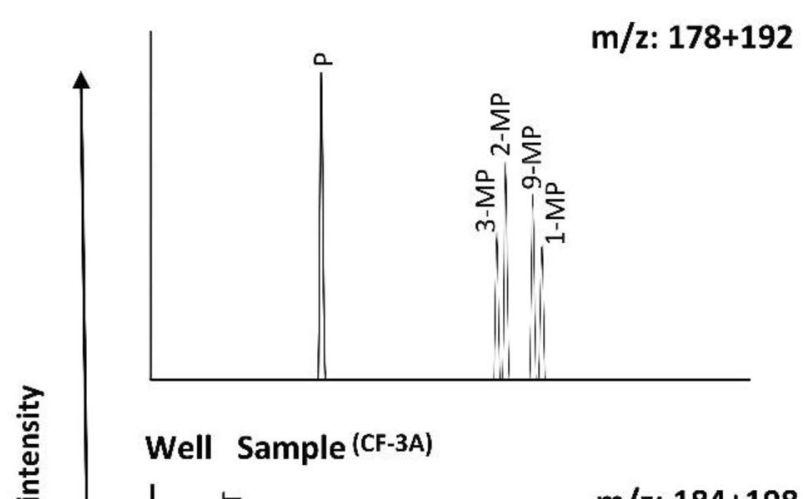

Outcrop Sample (CF-1B)

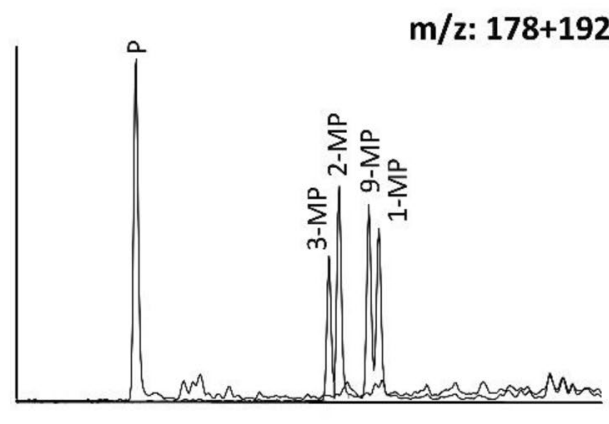

Outcrop Sample (CF-1B)

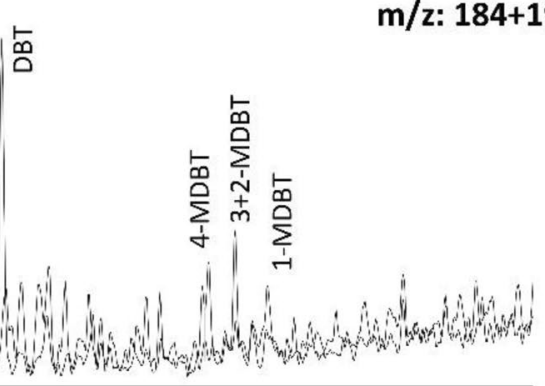

Relative retention time

Fig. 14 Aromatic hydrocarbon composition; top 2 are the representative chromatograms that show distribution of P and MP, and bottom 2 are the representative chromatograms that show relative abundance of DBT and MDBT

n-alkanes, low values of $\mathrm{Pr} / \mathrm{Ph}(<1)$, low values of different tricyclic terpanes (i.e., $\mathrm{C}_{19} / \mathrm{C}_{23}, \mathrm{C}_{20} / \mathrm{C}_{23}, \mathrm{C}_{26} / \mathrm{C}_{25}$ ), high TCT/H ratios, high $\mathrm{C}_{27}$ steranes as compared to $\mathrm{C}_{29}$ steranes and absence of terrestrial biomarker (oleanane). The integrated geochemical and petrographical studies reveal that the shales of the Chichali Formation were deposited in anoxic environment with type II kerogen having poor to good hydrocarbon potential.

Acknowledgements The Higher Education Commission (HEC) of Pakistan is gratefully acknowledged for providing financial assistance to conduct this research. The Oil and Gas Development Company Limited (OGDCL) of Pakistan is thanked for providing well cuttings and laboratory facilities. We also extend our appreciation to the Hydrocarbon Development Institute of Pakistan (HDIP) for providing help in this research.

Open Access This article is licensed under a Creative Commons Attribution 4.0 International License, which permits use, sharing, adaptation, distribution and reproduction in any medium or format, as long as you give appropriate credit to the original author(s) and the source, provide a link to the Creative Commons licence, and indicate if changes were made. The images or other third party material in this article are included in the article's Creative Commons licence, unless indicated otherwise in a credit line to the material. If material is not included in the article's Creative Commons licence and your intended use is not permitted by statutory regulation or exceeds the permitted use, you will need to obtain permission directly from the copyright holder. To view a copy of this licence, visit http://creativecommons.org/licenses/by/4.0/.

\section{References}

Ahmad S (2003) A comparative study of structural styles in the Kohat Plateau, North West Himalayas, NWFP, Pakistan. Unpublished Ph.D Thesis, NCE in Geology, University of Peshawar, pp 1-119

Ahsan N, Chaudhry MN (2008) Geology of Hettangian to Middle Eocene Rocks of Hazara and Kashmir Basins, Northwest Lesser Himalayas. Pakistan Geol Bull Punjab Univ 43:131-152

Abbasi IA, McElroy R (1991) Thrust kinematics in the Kohat Plateau, Trans Indus Range. Pakistan Journal of Structural Geology 13(3):319-327. https://doi.org/10.1016/0191-8141(91)90131-2

Bacon CN, Calver CR, Boreham CJ, Lenman DE, Morrison KC, Revill AT, Volkman JK (2000) The Petroleum Potential of Onshore Tasmania: a review. Geological Survey Bulletin 71:1-93

Bourbonniere RA, Meyers PA (1996) Sedimentary geolipid records of historical changes in the watersheds and productivities of Lakes Ontario and Erie. Limnol Oceanogr 41:352-359

Brooks JD, Gould K, Smith J (1969) Isoprenoid hydrocarbons in coal and petroleum. Nature 222:257-259

Chakhmakhchev A, Suzuki N (1995) Saturate biomarkers and aromatic sulfur compounds in oils and condensates from different source rock lithologies of Kagakhan. Jpn Russia Org Geochem 23:289-299 
Cranwell PA, Eglinton G, Robinson N (1987) Lipids of aquatic organisms as potential contribution to lacustrine sediments-II. Org Geochem 11:513-527

Didyk BM, Simoneit BRT, Brassell SC, Eglinton G (1978) Organic geochemical indicators of paleo environmental conditions of sedimentation. Nature 272:216-222

Espitalié J, Madec M, Tissot B, Menning JJ, Leplat P (1977) Source rock characterization methods for petroleum exploration. In: Proceedings of offshore technology Houston Texas, pp 439-444

Espitalié J, Deroo G, Marquis F (1985). Rock-eval pyrolysis and its application. 2. Revue De L Institut Francais Du Petrole 40(6):755-784.

Espitalié J, Deroo G, Marquis F (1986) Rock-Eval pyrolysis and its applications. Part III. Revue de l'Institut Français du Petrole 41(1):73-89.

Gardezi SAH, Ahmad S, Rehman G, Ikram N (2017) Geological constraints on western kohat foreland basin, Khyber Pakhtunkhwa, Pakistan: Implication from $2 \mathrm{~d}$ and $3 \mathrm{~d}$ structural modeling. Arab J Earth Sci 4(2):95-116

Hao F, Zhou XH, Zhu YM, Zou HY, Yang YY (2010) Charging of oil fields surrounding the Shaleitian uplift from multiple source rock intervals and generative kitchens, Bohai Bay basin. China Mar Pet Geol 27:1910-1926

Hughes WB, Holba AG, Dzou LI (1995) The ratio of dibenzothiophene to phenanthrene and pristane to phytane as indicators of depositional environment and lithology of petroleum source rocks. Geochim Cosmochim Acta 59:3581-3598

Hunt JM (1979) Petroleum geochemistry and geology. WH Freeman, San Francisco

Kadri IB (1995) Petroleum Geology of Pakistan. Pakistan Petroleum Ltd, Karachi 30:275p

Langford FF, Blanc-Valleron MM (1990) Interpreting Rock-Eval pyrolysis data using graphs of pyrolyzable hydrocarbons vs. total organic carbon. Am Asso Petrol Geol Bull 74:799-804

Meissner CR, Master JM, Rashid MA, Hussain M (1974) Stratigraphy of Kohat Quadrangle Pakistan. Geological investigation in Pakistan, USGS Professional paper 716D, U.S. Geological Survey, pp 130.

Peters KE (1986) Guidelines for evaluating petroleum source rock using programmed pyrolysis. AAPG Bull 70:318e329.

Peters KE, Cassa MR (1994) Applied source rock geochemistry, chapter 5, AAPG Memoir 60, 93-120. In: Magoon LB, Dow WG. (eds) The petroleum system-from source to trap

Peters KE, Walters CC, Moldowan JM (1993) The biomarker guide, biomarkers and isotopes in petroleum systems and human history, 1st edn. Prentice Hall Inc, United Kingdom

Peters KE, Walters CC, Moldowan JM (2005) The biomarker guide, biomarkers and isotopes in petroleum systems and human history, second edition, Cambridge Press, United Kingdom, vol II, pp 475-963

Powell TG, McKirdy DM (1973) Relationship between ratio of pristane to phytane, crude oil composition and geological environment in Australia. Nature 243:37-39

Radke M (1988) Application of aromatic compounds as maturity indicators in source rocks and crude oils. Mar Pet Geol 5:224-236

Radke M, Welte DH, Willsch H (1982) Geochemical study on a well in the Western Canada Basin: relation of the aromatic distribution pattern to maturity of organic matter. Geochim Cosmochim Acta 46:1-10

Rehman G, Ahmad S, Zahid M, Ali F (2009) Structural Geology of the Shakar Khel Area, Karak District, Khyber Pakhtunkhwa Pakistan. Pak J Hydro Res 19:11-17

Seifert WK, Moldowan JM (1980) The effect of thermal stress on source rock quality as measured by hopane stereochemistry. Phys Chem Earth 12:229-237

Seifert WK, Moldowan JM (1986) Use of biological markers in petroleum exploration. In: Johns RB (ed.) Methods in geochemistry and geophysics, vol. 24. Elsevier, Amsterdam, pp 261-90

Shah SMI (2009) Stratigraphy of Pakistan. Geological Survey of Pakistan, Memoir, vol 22, 381

Shanmugam G (1985) Significance of coniferous rain forests and related organic matter in generating commercial quantities of oil, Gippsland Basin, Australia. Am Asso Petrol Geol Bull 69:1241-1254

Tenzer GE, Meyers PA, Ribbins JA, Eadie BJ, Morehead NR, Lansing MB (1999) Sedimentary organic matter record of recent environmental changes in the St. Marys River ecosystem

Tissot BP, Welte DH (1984) Petroleum Formation and Occurrence, 2nd edn. Springer Verlag, New York

Van Krevelen DW (1984) Organic geochemistry—old and new. Org Geochem 6:1-10

Wandrey CJ, Law BE, Shah HA (2004) Patala-Nammal composite total petroleum system, Kohat-Potwar geological province, Pakistan. United States Geological Survey Bulletin Open File Report 2208B, pp 1-18

Yeats RS, Hussain A (1987) Timing of structural events in the Himalayan foothills of northwestern Pakistan. Geol Soc Am Bull 99:161-176

Publisher's Note Springer Nature remains neutral with regard to jurisdictional claims in published maps and institutional affiliations. 